\title{
Student-Led Clinics in Aotearoa New Zealand: A Scoping Review with Stakeholder Consultation
}

\author{
Ema Tokolahi $\mathbb{D}^{1,2}$ \\ Patrick Broman' \\ Glynis Longhurst' \\ Amy Pearce (D)' \\ Cassandra Cook' \\ Patrea Andersen 1,3,4 \\ Sharon Brownie ${ }^{1,5}$
}

'Centre for Health and Social Practice/ Centre for Sports Science and Human Performance, Wintec, Hamilton, New Zealand; ${ }^{2}$ School of Occupational Therapy, Otago Polytechnic, Dunedin, New Zealand; ${ }^{3}$ School of Nursing, Midwifery and Paramedicine, University of the Sunshine Coast, Sunshine Coast, Queensland, Australia; ${ }^{4}$ School of Nursing, Midwifery and Social Science, CQUniversity, Rockhamptom,

Queensland, Australia; ${ }^{5}$ School of Medicine, Griffith University, Gold Coast, Queensland, Australia
Correspondence: Ema Tokolahi

Wintec, Centre for Health and Social

Practice, Private Bag 3036, Hamilton,

3240, New Zealand

Tel +64 78348800

Email ema.tokolahi@wintec.ac.nz
Background: Student-led clinics have gained increasing attention as a mechanism for students across various health professions to gain authentic interprofessional clinical placement experience during their educational programme.

Purpose: This scoping review is designed to identify and describe experiences relating to student-led clinics in Aotearoa New Zealand.

Methods: The review involved five key steps: 1) identifying the research question; 2) identifying relevant studies; 3) study selection; 4) charting the data; and 5) collating, summarising and reporting the results.

Discussion: Student-led health clinics present invaluable educational opportunities for authentic collaborative practice and capacity to improve population health and well-being, especially in marginalised and disadvantaged communities. Clinic establishment and operation require consideration of a complex set of factors.

Conclusion: Community consultation (including with Indigenous populations) should precede establishment of clinics. There is scope for more reporting and objective evaluation to ensure best practice is being determined, developed, and achieved.

Keywords: student run clinic, student-led clinic, interprofessional education, clinical practicum

\section{Introduction}

Student-led clinics (SLCs) have gained increasing attention as a mechanism for students across various health professions to gain authentic interprofessional clinical placement experience during their educational programme. ${ }^{1,2}$ Capacity for SLCs to improve the health and well-being, especially in marginalised and disadvantaged communities, is well documented. ${ }^{3-7}$ While an increasing global body of knowledge considers the nature, characteristics and outcomes achieved by SLCs, literature relating to such clinics in the Aotearoa New Zealand ${ }^{(i)}$ context has not previously been synthesised. Aotearoa New Zealand is a particularly useful context to explore these questions. It is one of the so-called CANZUS states (Canada, Australia, New Zealand and the United States), ${ }^{8,9}$ all Anglosettler states home to politically active Indigenous minorities. ${ }^{10}$ Indigenous populations in all of these countries experience significant health disparity, for which colonisation has been described as the "cause of causes". ${ }^{11}$ Aotearoa New Zealand is distinctive amongst CANZUS states in having an Indigenous "majority minority", with Māori making up $16.5 \%$ of the population. ${ }^{12}$ It has a particularly high percentage of foreign-born people $27 \%$, compared for example to $14 \%$ in the United States. ${ }^{13}$ It is thus an obvious example of the "superdiversity"14 countries increasingly experience across the world, and the 
formal government commitment to biculturalism and the visibility of Māori offer a unique and interesting dimension to questions of health and policy.

The purpose of this scoping review is therefore to identify and describe experiences and outcomes relating to SLCs in Aotearoa New Zealand. Scoping reviews, as defined by Daudt et al. ${ }^{15}$

map the literature on a particular topic or research area and provide an opportunity to identify key concepts; gaps in the research; and types and sources of evidence to inform practice, policymaking, and research. (p. 48)

They are particularly suited to areas of focus that have not previously been comprehensively reviewed, and have the benefit of allowing the incorporation of very broad sources of information, methodologies and study design in gaining a comprehensive overview of a topic. ${ }^{16,17}$ Unlike a systematic review, a scoping review does not include detailed quality analysis of identified items. ${ }^{18,19}$ As some SLCs exist in Aotearoa New Zealand that have not been the focus of published study, the review was augmented by provider consultation to corroborate and validate findings.

An understanding of prior SLC experiences is an important precursor when considering incorporating of this type of clinical experience within educational programmes. The specific area of focus for this review is therefore on the practical operation of SLCs in Aotearoa New Zealand, as an example of CANZUS state. We concentrate specifically on the ways in which these clinics have been designed, implemented, and evaluated, and on gaps in the literature that warrant further research.

\section{Methods}

The methodological framework for this scoping review was informed by the work of Arksey and O'Malley ${ }^{20}$ with later refinements by Colquhoun et al. ${ }^{21}$ and Tricco et al. ${ }^{22}$ The review involved five key steps: 1) Identifying the research question; 2) identifying relevant studies; 3) study selection; 4) charting the data; and 5) collating, summarising and reporting the results. An optional "consultation" step of the framework was also included. To balance rigor with the efficient use of available resources, ${ }^{23}$ one author completed the initial literature search, while subsequent screening and review was distributed amongst authors. Each source identified in the literature was allocated to at least two authors for separate data screening and charting.
Authors subsequently used existing connections to arrange consultation interviews with key individuals in five student-led clinics across Aotearoa New Zealand. Analysis of data collected via consultation interviews was completed by one author before being circulated to other authors and to interviewees for further feedback and refinement.

\section{Identifying the Research Question}

Scoping reviews are typically less precise and broader in nature than systematic reviews. ${ }^{19,24}$ As such this review was guided by a range of questions as outlined in Table 1 . The foci guiding this review were 1) general characteristics of SLCs in Aotearoa New Zealand; 2) underpinning models used in SLCs in Aotearoa New Zealand; 3) consultation with communities and with Māori; 4) lessons learned from implementing SLCs in the Aotearoa New Zealand context; and 5) evaluation of SLCs in Aotearoa New Zealand.

Table I Research Questions

\begin{tabular}{|c|c|}
\hline Aspects & List of Questions \\
\hline \multirow[t]{2}{*}{ General } & $\begin{array}{l}\text { What types of SLCs currently exist in } \\
\text { Aotearoa New Zealand? }\end{array}$ \\
\hline & What patient populations are served? \\
\hline \multirow[t]{2}{*}{ Underpinning model } & What models of practice are utilised? \\
\hline & What is the scope of student contributions? \\
\hline \multirow[t]{3}{*}{$\begin{array}{l}\text { Cultural/community } \\
\text { considerations }\end{array}$} & $\begin{array}{l}\text { How were communities consulted in clinic } \\
\text { development, implementation, and } \\
\text { evaluation? }\end{array}$ \\
\hline & $\begin{array}{l}\text { What cultural supports are available to } \\
\text { students (and staff) during placement at } \\
\text { a SLC? }\end{array}$ \\
\hline & $\begin{array}{l}\text { What cultural/Te Ao Māori practices are } \\
\text { incorporated into SLCs? }\end{array}$ \\
\hline Implementation & $\begin{array}{l}\text { With regards to developing and } \\
\text { implementing a SLCs, what were the } \\
\text { reported: } \\
\text { - Benefits? } \\
\text { - Challenges? } \\
\text { - Lessons? }\end{array}$ \\
\hline \multirow[t]{2}{*}{ Evaluation } & $\begin{array}{l}\text { How were SLCs evaluated? What outcomes } \\
\text { were measured (eg student, academic, } \\
\text { community)? }\end{array}$ \\
\hline & What methods were used? \\
\hline
\end{tabular}




\section{Locating Relevant Studies}

As the start point, a search strategy was developed that followed Arksey and O'Malley's ${ }^{20}$ recommendations to search several multiple sources, including electronic databases, reference lists, and hand searching of key journals or authors. The intention was to create a broad, sensitive search rather than a narrow specific search. Search terms were selected that focused on SLCs in the Aotearoa New Zealand context (see Box 1). Search terms were entered into several electronic databases including PubMed and CINAHL Complete, Health Source, SOCindex, SPORTDiscus, and Vocational Studies Complete (via EBSCOHost). Where the name of an author appeared more than once in literature about SLCs, an internet search was conducted to identify any other relevant publications. Reference lists of identified articles were also screened for additional relevant publications. A Google search was also conducted, with the first 100 hits screened. All citations were imported into the web-based reference management software Mendeley, ${ }^{25}$ and duplicate citations removed.

\section{Study Selection}

Study selection followed a two-stage screening process to determine the relevance of studies identified from the searches. Initially, studies were considered eligible if the title or abstract referred to SLC's and appeared to include students from Aotearoa New Zealand, if it had an Aotearoa New Zealand-based author, or if the location was not clear. Study selection was limited to publications in English, however, no restrictions were set on date or type of publications selected.

The second stage of screening involved obtaining a full-text copy of each of the 17 publications selected in the initial screening and reviewing these to confirm: 1) the SLC involved direct contact with an end-user (eg client or patient); 2) at least one of the SLCs reported on was based in Aotearoa New Zealand and 3) the SLC had a health

\section{Box I Search Terms}

Tertiary OR student* OR undergraduate* OR graduate* OR
volunteer*

AND led OR run OR facilitated OR managed OR assisted

AND service* or centre* OR center* OR clinic*

AND Zealand OR Māori OR Maori OR Maaori OR kaupapa

Notes: *Indicates use of a wildcard symbol that broadens the search to words that begin the same but may have different endings, for example "centre*" would find "centre", "centres" and "centred". focus. Publications were excluded if the clinical experience involved simulations or teaching only without direct provision of care. Articles were selected independently by more than one author to monitor consistency, with no disagreements about article selection. To increase clarity of our review process, the preferred reporting for systematic reviews and meta-analysis (PRISMA) was used to provide a visual illustration of the screening and selection process (see Figure 1).

\section{Data Extraction and Synthesis}

To extract pertinent data from each included study Joanna Briggs Institute (JBI) guidelines for data extraction were followed. ${ }^{26}$ Extracted data included: author/s, year of publication, location of the SLC, how the SLC was defined and the population served. Data abstraction tables were developed that related to each of the remaining aspects of the study research questions: 1) underpinning model; 2) community consultation; 3) implementation: opportunities, barriers, and lessons; and 4) evaluation. At least two research team members independently extracted data from each study and the tables were reviewed by all study team members. Data were analyzed for themes and frequencies by at least two members with preliminary results reviewed and negotiated by the team until consensus was achieved.

\section{Consultation}

In a scoping review of scoping reviews ${ }^{27}$ less than $40 \%$ of studies were found to include a consultation exercise as part of the scoping review method. Stakeholders were most often consulted in the search phase (to identify key search terms) and, more rarely, during the interpretation of findings or for providing feedback during the report writing stage. This scoping review utilised consultation with stakeholders (current education providers) for the purposes of a) identifying additional relevant literature to include in the review, b) elaborating further on details reported on each SLC, and c) gaining knowledge of additional SLCs not having previously been published on. Ethical approval for this consultation was sought and granted by the Wintec Human Research Ethics Group (WTFE14130820).

\section{Results}

Table 2 shows the article selection. A total of 10 articles met the eligibility criteria, with the earliest being a thesis published in 2012. ${ }^{28}$ The small and recent nature of the literature reflects the relatively novel nature of SLCs in Aotearoa New Zealand. 


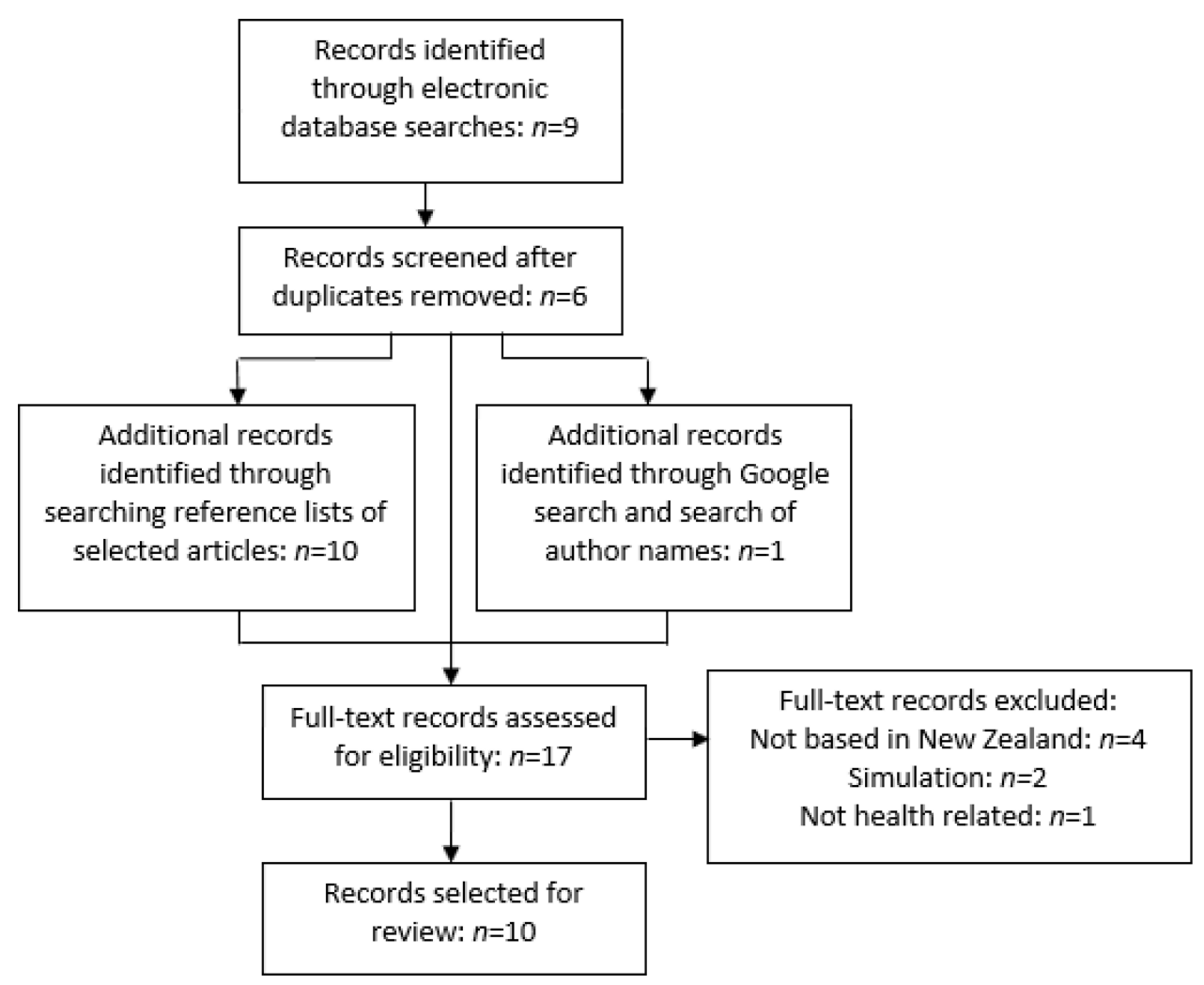

Figure I PRISMA flow diagram.

Note: Adapted from Liberati A, Altman D, Tetzlaff J, et al. The PRISMA statement for reporting systematic reviews and meta-analyses of studies that evaluate health care interventions: explanation and elaboration. Journal of Clinical Epidemiology. 2009;62(10)el-e34. Creative Commons. ${ }^{64}$

\section{General Characteristics of Student-Led Clinics}

An overview of each clinic is described in Table 3. Six documents related to Auckland University of Technology's (AUT) Integrated Health Interprofessional programmes; ${ }^{28-33}$ additional information about this centre, as a centre for developing clinical skills and knowledge, was gained through the consultation process. The remaining documents referred, respectively, to a clinic collaboration between AUT and Auckland District Health Board, ${ }^{34}$ an IP learning experience at University of Otago, ${ }^{35}$ data from several osteopathy SLCs including one based at Unitec, Auckland ${ }^{36}$ and data from unspecified student clinics including three from Aotearoa New Zealand. ${ }^{37}$ Consultation with education providers resulted in information being collected from a further four clinics involving a range of disciplines and institutions in Aotearoa New Zealand (see Table 4).

\section{Underpinning Models of Practice}

The scope of student contributions varied across the clinics, with most providing opportunities for students to independently plan and deliver a service directly to clients. Four of the clinics reported using a business or private practice model, charging for services, and operating much as they would in the commercial marketplace. One student-led clinic was project-based and involved a collaboration between two organizations: this placement was not necessarily aligned with a physical clinic space and service provision was not expected to be sustained beyond the placement experience. With one exception, ${ }^{37}$ all the clinics identified in the literature involved students from more than one profession, while the additional clinics identified through consultation involved only one profession. Educational models described were the scientistpractitioner model, interprofessional care-based model, Wenger model of Communities of Practice (which was reported to have since gone out of favour with this clinic), and a client-centred, collaborative, holistic, and interprofessional care model (see Table 5 for details).

\section{Community Consultation}

None of the included documents described community consultation, including with Māori (Indigenous population), as 
Table 2 Location, Type and Focus of Documents Included in Scoping Review

\begin{tabular}{|c|c|c|c|c|}
\hline Ref & $\begin{array}{l}\text { First Author } \\
\text { (Alphabetical) }\end{array}$ & Location & $\begin{array}{l}\text { Document } \\
\text { Type }\end{array}$ & Focus \\
\hline [37] & Allan et al $201 \mathrm{I}$ & $\begin{array}{l}\text { Unspecified: three clinics in Aotearoa } \\
\text { New Zealand plus seventeen clinics } \\
\text { across Australia }\end{array}$ & $\begin{array}{l}\text { Research } \\
\text { article }\end{array}$ & $\begin{array}{l}\text { Consultative enquiry of the goals, possibilities, and challenges } \\
\text { of clinics and conceptualising and describing the role of } \\
\text { context, particularly rural, for these clinics. }\end{array}$ \\
\hline [29] & Friary et al 2018 & $\begin{array}{l}\text { Auckland University of Technology, } \\
\text { Auckland }\end{array}$ & $\begin{array}{l}\text { Research } \\
\text { article }\end{array}$ & $\begin{array}{l}\text { Phenomenological exploration of the experiences of clients, } \\
\text { students and educators associated with a university clinic- } \\
\text { based interprofessional programme for clients with } \\
\text { Parkinson's disease. }\end{array}$ \\
\hline [34] & $\begin{array}{l}\text { Godbold et al } \\
2019\end{array}$ & $\begin{array}{l}\text { Auckland University of Technology and } \\
\text { Auckland District Health Board, } \\
\text { Auckland }\end{array}$ & $\begin{array}{l}\text { Opinion } \\
\text { article }\end{array}$ & $\begin{array}{l}\text { Reflection on the ethical issues raised for students in an } \\
\text { interprofessional clinic through the application of a human- } \\
\text { centred approach to design in a collaborative health context. }\end{array}$ \\
\hline [30] & $\begin{array}{l}\text { Morgan et al } \\
2019\end{array}$ & $\begin{array}{l}\text { Auckland University of Technology, } \\
\text { Auckland }\end{array}$ & $\begin{array}{l}\text { Research } \\
\text { article }\end{array}$ & $\begin{array}{l}\text { Mixed methods study exploring the learning experiences of } \\
\text { health students, clinical educators, interprofessional } \\
\text { facilitators and health administrators associated with } \\
\text { a student clinic pilot programme for patients living with type } \\
2 \text { diabetes. }\end{array}$ \\
\hline [3I] & $\begin{array}{l}\text { O'Brien et al } \\
2013\end{array}$ & $\begin{array}{l}\text { Auckland University of Technology, } \\
\text { Auckland }\end{array}$ & $\begin{array}{l}\text { Research } \\
\text { article }\end{array}$ & $\begin{array}{l}\text { Mixed methods study exploring student beliefs and attitudes } \\
\text { regarding clinical placements at a university clinic that aim to } \\
\text { develop interprofessional collaborative practice. }\end{array}$ \\
\hline [32] & $\begin{array}{l}\text { O'Brien et al } \\
2016\end{array}$ & $\begin{array}{l}\text { Auckland University of Technology, } \\
\text { Auckland }\end{array}$ & $\begin{array}{l}\text { Research } \\
\text { article }\end{array}$ & $\begin{array}{l}\text { Mixed methods study exploring and evaluating the outcomes } \\
\text { and experiences of clients, staff and students piloting an } \\
\text { integrated interprofessional programme for community } \\
\text { members with type } 2 \text { diabetes. }\end{array}$ \\
\hline [33] & $\begin{array}{l}\text { O'Brien et al } \\
2015\end{array}$ & $\begin{array}{l}\text { Auckland University of Technology, } \\
\text { Auckland }\end{array}$ & $\begin{array}{l}\text { Research } \\
\text { article }\end{array}$ & $\begin{array}{l}\text { Understanding the organization of interprofessional student } \\
\text { learning opportunities through mapping key participants, } \\
\text { practices, and structures in an interprofessional student-led } \\
\text { health service. }\end{array}$ \\
\hline [35] & $\begin{array}{l}\text { Pullon et al } \\
2013\end{array}$ & University of Otago, Wellington & $\begin{array}{l}\text { Research } \\
\text { article }\end{array}$ & $\begin{array}{l}\text { Mixed methods study testing the feasibility of delivering an } \\
\text { interprofessional-based course component to health } \\
\text { students, including home visits. }\end{array}$ \\
\hline [28] & Tucker 2012 & $\begin{array}{l}\text { Auckland University of Technology, } \\
\text { Auckland }\end{array}$ & MPhil Thesis & $\begin{array}{l}\text { Qualitative descriptive exploration of service user's } \\
\text { experiences, expectations and understanding of care } \\
\text { received at an interprofessional student-lead health service. }\end{array}$ \\
\hline [36] & Vaughan 2018 & $\begin{array}{l}\text { Unitec Institute of Technology, } \\
\text { Auckland, plus two in Australia and one } \\
\text { in the United Kingdom }\end{array}$ & $\begin{array}{l}\text { Research } \\
\text { article }\end{array}$ & $\begin{array}{l}\text { Implementing Rasch analysis to investigate the construct } \\
\text { validity of the Osteopathy Clinical Teaching Questionnaire as } \\
\text { a tool for evaluating clinical education in an on-campus, } \\
\text { student-led osteopathy clinic environment. }\end{array}$ \\
\hline
\end{tabular}

part of the process for developing or implementing the student-led clinical experiences. We consider three studies $^{35,37,38}$ might have been expected to include such information as relevant to discussion about the feasibility, development or conceptualisation of the student-led service. Similarly, descriptions of practices inclusive of Te Ao Māori (Indigenous worldview), cultural support for students, educators or community members, and marketing of the student-led health service to Māori were not discussed in any of the included documents.

In terms of incorporating Indigenous models of care, when asked how clinic practices reflect Te Ao Māori, one provider reported including an introduction to some "dos and don'ts" of working with Māori clients in their student 
Table 3 Characteristics of Student-Led Clinics Identified in the Literature

\begin{tabular}{|c|c|c|c|}
\hline $\begin{array}{l}\text { Student-Led Clinics } \\
\text { (Alphabetical) }\end{array}$ & Description of Student-Led Health Service & $\begin{array}{l}\text { Student Disciplines } \\
\text { (Alphabetical) }\end{array}$ & Population Served \\
\hline $\begin{array}{l}\text { Auckland University of } \\
\text { Technology Integrated } \\
\text { Health - Interprofessional } \\
\text { programmes* }\end{array}$ & $\begin{array}{l}\text { One-day/week, seven to twelve-week programmes: } \\
\text { includes IP in-service, IP appointments, IP education and } \\
\text { interactive discussion-based sessions, IP group tutorial } \\
\text { sessions and IP client focused care conferences led by } \\
\text { health students. }\end{array}$ & $\begin{array}{l}\text { - } \text { Case management } \\
\text { - } \text { Exercise and nutrition } \\
\text { - } \text { Health administration } \\
\text { - Health promotion } \\
\text { - Nursing } \\
\text { - Occupational therapy } \\
\text { - } \text { Oral health } \\
\text { - Physiotherapy } \\
\text { - Podiatry } \\
\text { - Psychotherapy }\end{array}$ & $\begin{array}{l}\text { Staff, students, and local community; three documents } \\
\text { focused specifically on patients with Parkinson's disease } \\
\text { and type } 2 \text { diabetes. }\end{array}$ \\
\hline $\begin{array}{l}\text { Design for Health and } \\
\text { Well-being }(\mathrm{DHW}) \text { Lab }\end{array}$ & $\begin{array}{l}\text { Students at both undergraduate and postgraduate levels } \\
\text { engage with a hospital through a design lab and have } \\
\text { access to the real-world context of acute health care. }\end{array}$ & - Design & District Health Board acute health services. \\
\hline $\begin{array}{l}\text { Three unspecified clinics } \\
\text { from New Zealand and } \\
\text { seventeen from Australia }\end{array}$ & $\begin{array}{l}\text { The most common clinic type described was an on- } \\
\text { campus university clinic provided by a single professional } \\
\text { group, often co-located with other clinics. }\end{array}$ & $\begin{array}{l}\text { - } \text { Audiology } \\
\text { - } \text { Dental } \\
\text { - } \text { exercise physiology } \\
\text { - } \text { Multidisciplinary } \\
\text { - Podiatry } \\
\text { - Physiotherapy } \\
\text { - Psychology } \\
\text { - } \text { Psychotherapy } \\
\text { - } \text { Occupational therapy } \\
\text { - Optometry } \\
\text { - Speech } \\
\text { - } \text { Veterinary }\end{array}$ & $\begin{array}{l}\text { Varied but not reported in detail: urban and rural; } \\
\text { typically run in partnership with healthcare providers or } \\
\text { near existing populations of high need eg aged care } \\
\text { facility; target high waiting lists. }\end{array}$ \\
\hline $\begin{array}{l}\text { Unitec Osteopathy clinic } \\
\text { (and others from Australia } \\
\text { and the United Kingdom) }\end{array}$ & $\begin{array}{l}\text { Osteopathy students are responsible for the management } \\
\text { of patients; approximately five to seven students are } \\
\text { simultaneously supervised by a qualified osteopath. }\end{array}$ & - Osteopathy & Not described. \\
\hline University of Otago & $\begin{array}{l}\text { Groups of three health students undertook a home visit } \\
\text { with a patient; students worked together to share } \\
\text { decision-making, construct a joint management plan, and } \\
\text { make recommendations. }\end{array}$ & $\begin{array}{l}\text { - } \text { Dietetics } \\
\text { - } \text { Medicine } \\
\text { - } \\
\text { Physiotherapy }\end{array}$ & $\begin{array}{l}\text { Patients attending a local primary care provider and } \\
\text { receiving health care for a number of comorbidities. }\end{array}$ \\
\hline
\end{tabular}

Note: *Also included in the consultation process.

orientation and having reminders of greetings in a range of languages, including Te Reo Māori, visible on the walls. Another referred to providing students with instructions about how to demonstrate respect for tapu (sacred) areas of the body. An ongoing relationship with a local Māori health provider was reported in relation to one of the clinics, specifically as a referrer of clients, although no targeted engagement was described.

\section{Development and Implementation of Student-Led Clinics}

Findings about the opportunities, challenges and learnings associated with developing and implementing student-led clinics were drawn from both the literature and the consultation with current education providers and are summarised in Box 2, Table 6 and Box 3.

\section{Evaluation of Student-Led Clinics}

Of the student-led clinics reported in the literature and included in the consultation process, Auckland University of Technology's Integrated Health Centre was the clinic evaluated formally the most extensively (see Table 7). Several of the consulted education providers had conducted informal evaluations reported within their institution but not published or disseminated more widely. Reported evaluations were primarily qualitative interviews or focus groups, with some inclusion of clinical outcomes as an objective measure of impact. One study evaluated the operational elements of student-led clinics. ${ }^{37}$ 
Table 4 Characteristics of Additional Student-Led Clinics Consulted

\begin{tabular}{|c|c|c|c|}
\hline $\begin{array}{l}\text { Student-Led } \\
\text { Clinics } \\
\text { (Alphabetical) }\end{array}$ & Description of Student-Led Health Service & $\begin{array}{l}\text { Student } \\
\text { Disciplines } \\
\text { (Alphabetical) }\end{array}$ & Population Served \\
\hline $\begin{array}{l}\text { Otago } \\
\text { Polytechnic } \\
\text { Massage Clinic }\end{array}$ & $\begin{array}{l}\text { Undergraduate massage programme students deliver } \\
\text { massage therapy and write client notes under } \\
\text { supervision (approx. student:staff ratio 3:I). Students } \\
\text { complete } 50-70 \text { hours at the clinic/year depending on } \\
\text { level of study. }\end{array}$ & - Massage & $\begin{array}{l}\text { Self-referrals of staff, students, and general } \\
\text { public. }\end{array}$ \\
\hline $\begin{array}{l}\text { University of } \\
\text { Otago } \\
\text { Physiotherapy } \\
\text { Clinic }\end{array}$ & $\begin{array}{l}\text { Undergraduates in } 2 \text { nd- } 4 \text { th year of study and } \\
\text { postgraduates deliver treatment under the supervision } \\
\text { of a registered physiotherapist. Placement lengths vary } \\
\text { between I morning/week for } 3 \text { weeks to } 6 \text { weeks full } \\
\text { time (approx. student:staff ratio } 4: 1 \text { ). }\end{array}$ & - Physiotherapy & $\begin{array}{l}\text { Self-referrals of students, staff, and general } \\
\text { public with musculoskeletal injuries and balance } \\
\text { challenges. }\end{array}$ \\
\hline $\begin{array}{l}\text { Victoria } \\
\text { University } \\
\text { Psychology } \\
\text { Centre }\end{array}$ & $\begin{array}{l}\text { Students in 4-6th year of study (postgraduate clinical } \\
\text { psychology programme). Students lead care under } \\
\text { supervision of clinical psychologist. }\end{array}$ & - Psychology & $\begin{array}{l}\text { Self-referrals or via GPs for clients (children, } \\
\text { youth, and adults) with mild-moderate mental } \\
\text { health needs. }\end{array}$ \\
\hline $\begin{array}{l}\text { Wintec } \\
\text { Biokinetic Clinic }\end{array}$ & $\begin{array}{l}\text { Students design and run exercise programmes with } \\
\text { referred clients under supervision of accredited } \\
\text { clinical exercise physiologist. Programmes last } 8 \\
\text { weeks. }\end{array}$ & $\begin{array}{l}\text { - Clinical exercise } \\
\text { physiology }\end{array}$ & $\begin{array}{l}\text { Clients accessing the Green Prescription } \\
\text { programme through Sport Waikato; referrals } \\
\text { from local primary healthcare providers. }\end{array}$ \\
\hline
\end{tabular}

\section{Discussion}

In seeking to develop interprofessional, student-led clinics, there is risk of "reinventing the wheel" and not learning from the work of others. This review collates available Aotearoa New Zealand-based evidence, as an example of a CANZUS state, to inform the planning, development, and implementation of a student-led health service. It is worth acknowledging characteristics in the Aotearoa New Zealand health system that differentiate it from those overseas, including: a publicly funded, regionally administered delivery system; a state-funded accident compensation scheme; and a diverse private/non-government sector. Approximately one-third of the population have private health insurance to help pay for noncovered services and copayments (relevant to some services and products). ${ }^{39}$ These unique characteristics will have implications for the funding and systems planned for the development of a student-led clinic.

The limited amount and recency of published literature suggests student-led clinics are an emerging focus in the literature, relative to how long some clinics have been established (ie decades in several cases). There is scope for more reporting and objective evaluation of such clinics to ensure best practice is being determined, achieved, and developed.
The consultation process highlighted the gap between what, and how much, is occurring within tertiary education in Aotearoa New Zealand and what is being formally written about and disseminated. In comparing the clinics identified through the literature search and those from the consultation process, it became apparent that clinics were more likely to be written about if they involved a collaboration with industry partners or were designed to take an interprofessional approach within a single institution, which is consistent with the international literature also. ${ }^{40}$ The consultation process identified a range of single-profession clinics that were co-located and run by educational providers. This could be considered a form of publication bias ${ }^{41}$ that jeopardises the ability of tertiary-level health educators to deliver quality learning experiences informed by a robust evidence-base.

There was a wide discrepancy in how the identified student-led clinics were described and operated. Terms such as "clinic" and "health service" were common, with others choosing not to use either - "clinic" is used consistently throughout this discussion for consistency although it is acknowledged this may not always be the most appropriate term. Some educators indicated the use of "clinic" implied accreditation as a health provider and by not using that word felt they were more clearly identifiable as an 
Table 5 Models of Practice and Scope of Student Contributions Within Student-Led Clinics

\begin{tabular}{|c|c|c|}
\hline Student-Led Clinics & Model of Practice & Scope of Student Contributions \\
\hline $\begin{array}{l}\text { Auckland University of Technology } \\
\text { Integrated Health - Interprofessional } \\
\text { programmes* }\end{array}$ & $\begin{array}{l}\text { Business/private practice } \\
\text { model. }^{33} \\
\text { Informed by Wenger model of } \\
\text { Communities of Practice. } \\
\text { Client-centred, collaborative, } \\
\text { holistic, and interprofessional }^{29} \\
\text { care. }^{29-32}\end{array}$ & $\begin{array}{l}\text { Students plan and deliver interventions in an interprofessional } \\
\text { environment, under the supervision of an appropriately registered } \\
\text { health professional. } \\
\text { As part of the IP programme, students facilitate a one-hour } \\
\text { interactive self-management education group each week. Each } \\
\text { student is assigned one patient, and all patient appointments are } \\
\text { attended by student pairs from different disciplines. } \\
\text { Client-focused conferences, led by health students, are held each } \\
\text { week. Students reassess patients at the end of the program and } \\
\text { compile a comprehensive report sent to their GP. }\end{array}$ \\
\hline $\begin{array}{l}\text { Design for Health and Well-being } \\
(\mathrm{DHW}) \text { Lab }\end{array}$ & $\begin{array}{l}\text { Project-based defined as } \\
\text { research Industry partnership. }\end{array}$ & $\begin{array}{l}\text { Students engage in a collaborative design process with staff and } \\
\text { patients, working through ethics, data collection, and design process }\end{array}$ \\
\hline Otago Polytechnic massage clinic & $\begin{array}{l}\text { Business/private practice } \\
\text { model. }\end{array}$ & $\begin{array}{l}\text { Students plan and implement massages and write up client notes } \\
\text { independently. Second- and third-year students also set up } \\
\text { appointments directly, manage payments and pay expenses for use of } \\
\text { the space/materials. }\end{array}$ \\
\hline $\begin{array}{l}\text { Three unspecified clinics from New } \\
\text { Zealand and seventeen from Australia }\end{array}$ & $\begin{array}{l}\text { On-campus clinics provided by } \\
\text { a single professional group. }\end{array}$ & - \\
\hline $\begin{array}{l}\text { Unitec Osteopathy clinic (and others } \\
\text { from Australia and the United Kingdom) }\end{array}$ & - & - \\
\hline University of Otago & $\begin{array}{l}\text { Interprofessional, care-based } \\
\text { course component. }\end{array}$ & $\begin{array}{l}\text { In interprofessional groups of three, students arrange and undertake } \\
\text { a home visit to consult with patient with comorbidities. Students } \\
\text { then collaborate on group presentations for peers/teaching staff } \\
\text { outlining the person's conditions and develop a multidisciplinary } \\
\text { care/management plan. }\end{array}$ \\
\hline University of Otago physiotherapy clinic & $\begin{array}{l}\text { Business/private practice } \\
\text { model. }\end{array}$ & Students plan and implement treatments and record client notes. \\
\hline Victoria University psychology centre & $\begin{array}{l}\text { Business/private practice model } \\
\text { (subsidised by the university). } \\
\text { Scientist/practitioner model. }\end{array}$ & $\begin{array}{l}\text { Students provide psychological services, according to level of study, } \\
\text { from observation to leading. }\end{array}$ \\
\hline Wintec Biokinetic clinic & $\begin{array}{l}\text { Not-for-profit, structured } \\
\text { programme delivery. }\end{array}$ & $\begin{array}{l}\text { Students complete an assessment with clients and send a feedback } \\
\text { report to the referrer; plan and implement an 8-week intervention; } \\
\text { and complete a final feedback report. }\end{array}$ \\
\hline
\end{tabular}

education provider that had non-registered health professionals (ie, students) providing a health service. Clarity of this medico-legal terminology was important from the perspective of organizational responsibility and mitigation of liability risks that need to be considered when providing a health service to the public. Furthermore, there was inconsistency across disciplines and institutions around in the use of labels, such as: student-assisted, -led, -run, or -facilitated. Additional terms identified in a separate, systematic review of international student-led clinics (submitted) included service-learning (examples ${ }^{42-45}$ ) and student free-clinics (examples ${ }^{46-52}$ ), the apparent distinction for these being the model of operation making no charge on service users, whereas as some, but not all, student clinics charge nominal fees to cover costs. Across all variations, the initiatives described appeared to fulfil the same purpose - addressing a community health need and generating authentic learning experiences for the student. In order to make future searching and synthesizing of evidence more effective and better inform practice, this indicates a need to adopt more standardized nomenclature across the health disciplines and localities. 
Box 2 Benefits and Opportunities of Student-Led Clinics

\section{For students}

- Generate real-world opportunities to implement practice (clinical and operational) and contextualise teaching and learning.

- Exposure to a diversity of clinical presentations.

- Students gained a holistic appreciation of the person.

- Create understanding of authentic and effective interprofessional teamwork

- Learning can be scaffolded in a safe/controlled learning environment.

- Chance to give back to the community.

\section{For the community}

- Fill a healthcare gap and a meet community need: there is a demand for services.

- Provision of affordable, good quality healthcare.

- Interprofessional teamwork between students was enjoyed by clients.

- Interprofessional practice provided clients with a one-stop shop for accessing services.

\section{For educators}

- Collaborations with health provider partners: potential satellite services.

- Provides some of the necessary placements and practicum experiences students require.

- Consistent with government strategy and policies on health and well-being.

- Health practitioners all held accountable to the same overarching legislation (Health Practitioners Competence Assurance Act, 2003).

With regards to daily operations, some clinics had students working for only a few hours a fortnight to working full-time and over varying periods of time. Some clinics required students to engage in periods of directed educational components whilst others were entirely hands-on client-based work (with some planning and note-taking). In all the clinics, students conducted service delivery under some form of expert supervision. The heterogeneity of contexts is a potential barrier to evaluating and synthesising practice in student-led clinics. This also creates opportunities for each clinic to be tailored to the specific community and educational needs of the region and affiliated education and health providers.

In Aotearoa New Zealand, it is important to determine how best to uphold responsibilities under Te Tiriti $\mathrm{O}$ Waitangi/The Treaty of Waitangi when developing a health-related educational experience. Other CANZUS states will face similar obligations to their respective Indigenous populations. Positioning Māori as priority
Table 6 Challenges of Developing and Implementing StudentLed Clinics

\begin{tabular}{|c|c|}
\hline arner & $\begin{array}{l}\text { For the Academic } \\
\text { Institution }\end{array}$ \\
\hline $\begin{array}{l}\text { - Limited diversity in range of } \\
\text { conditions seen: high number of } \\
\text { - } \text { - Complients with the same problem. } \\
\text { - Interpersonal chronic conditions. } \\
\text { operation, and partnership. } \\
\text { - Differences and misunderstand- } \\
\text { ings in perceptions about what } \\
\text { students should do and learn. } \\
\text { - The volume and complexity of } \\
\text { knowledge and skills to be } \\
\text { acquired during interprofes- } \\
\text { sional teamwork can leave } \\
\text { a learner feeling uncertain. } \\
\text { - Logistics, such as "getting up in } \\
\text { the morning to information } \\
\text { overload".31 (p85) } \\
\text { - Arranging clinical contacts. }\end{array}$ & $\begin{array}{l}\text { - Do not generate all place- } \\
\text { ments required. } \\
\text { - Patient supply (except where } \\
\text { developed in response to } \\
\text { community need). } \\
\text { - Tension between curriculum } \\
\text { requirements, students' learn- } \\
\text { ing needs and patient needs. } \\
\text { - Timetabling. } \\
\text { - Continuity of care: student } \\
\text { availability to run clinics } \\
\text { throughout the year. } \\
\text { - Operating as a healthcare } \\
\text { provider and accountability. } \\
\text { - Potentially in direct competi- } \\
\text { tion with other health } \\
\text { providers. } \\
\text { - Staffing: clinic management not } \\
\text { recognised in academic } \\
\text { workloads. }\end{array}$ \\
\hline
\end{tabular}

learners and priority health-service users is critical to reducing education and health inequalities, which will ultimately lift the socio-economic and health outcomes for the nation. ${ }^{53,54}$ Thus, questions were asked of the literature and education providers about consultation processes undertaken with Māori during clinic development and implementation. Consultation with Māori was not widely reported in the literature and while it cannot be concluded that consultation did not occur, the consultation process from this review (with education providers) indicated that it was not a common component in the development of clinics. This appears to have had an impact on the client populations accessing services, resulting in a low proportion of Māori clients.

Limited access of Māori clients in these contexts is significant. In order to lift the health outcomes for Māori, health providers must find ways of breaking down access barriers and ensuring Māori "consistently experience positive, high-quality healthcare interactions that support Māori ways of being", with current service provision being described as "hostile and alienating" 55 (p193). The literature suggests that locating clinics in an area of high need is insufficient for ensuring an ongoing and consistent supply of patients. Education providers should ensure students have access to learning opportunities which reflect 
Box 3 Lessons Learned About Developing and Implementing Student-Led Clinics

\section{Lessons about teaching and learning}

- Planning is required to provide consistent education and supply of expert supervision.

- Student experiences were positive, practice was transformative.

- Aligning participation with course requirements impacts attendance and commitment.

- Interprofessional components can be successfully introduced across existing pre-registration health professional degree courses in an Aotearoa New Zealand context.

- Clinics can provide an authentic interprofessional environment.

- A sharing of the vocabularies, cultures and worldviews of each disciplines requires making knowledge explicit to enable situated learning to occur.

- Aligning of curriculum is needed to facilitate consistent and sustainable interprofessional learning opportunities within a student-led clinic.

- Creation of practice stories and heuristics may be important in the NZ context.

- Educators gained valuable insight into their own collaborative processes and learning, and into difficult aspects of interprofessional teamwork for students.

\section{Lessons learned about operational factors}

- Start small and build up: do not over-reach or over-commit.

- Multi-perspective planning and staff facilitation is required for success.

- A clear vision and clinic objectives are essential.

- Policies and procedures need to support and reflect interprofessional practice and prevent siloed practices and communication.

- A focus on interprofessional practice should come from the leadership team.

- Plan to ensure ongoing supply and diversity of patients: locating in an area of high need is insufficient evidence this will occur.

- Successful examples were outreach clinics and partnerships with established healthcare providers.

- The physical environment can facilitate or inhibit effective interprofessional practice.

- Educational institutions operate within different financial arrangements than healthcare providers.

- Recommendation to operate as a quality healthcare provider and have strong processes in place for managing equipment and materials etc.

- Having a single point of entry for referrals is useful for external providers.

- Having a front-facing administrator can support health students to stay focused on clinical learning experiences with clients.

the healthcare sought or required in the community. Designing process and strategies for increasing access and reducing barriers for Māori to engage with services seems critical for generating authentic learning experiences for students.

This review identified several opportunities and benefits in developing and implementing student-led health services, for learners, communities, and the educational institutions. For learners it was evident that "real-world" learning through student-led clinics is generally perceived positively and can be transformational in nature. For students who may need extra scaffolding of their learning, student-led health services were described as a safe or controlled learning environment that could provide additional supports as required. Given the limitations in culturally informed practice reported, it would be useful to know if any of the additional supports indicated for students were relevant to their own or clients' cultural needs, and what opportunities this creates for partnership with a Māori health provider to embed culturally intelligent supports from the outset.

The diversity of patients accessing student-led health services was identified as both an opportunity and a barrier: with some populations presenting with highly diverse and complex conditions that generated rich learning experiences and some populations presenting with high rates of the same condition generating more repetitive learning experiences. Some of the opportunities and challenges identified in the literature by learners were not necessarily specific to the student-led health service context and could be considered applicable to student experiences of being on placements in general. ${ }^{56,57}$ For example, challenges were reported such as getting up in the morning and experiencing "information overload". ${ }^{31}$

For educators, student-led health services present invaluable opportunities to collaborate with other health providers and to provide flexible placements which align with the curriculum and programme requirements. In some instances, student-led health services delivered through an education provider were the only opportunity available for students to gain clinical learning experiences during their academic career. In other programmes, the student-led health service was in competition with other healthcare providers, putting strain on relationships. It was frequently reported that there was some level of inherent tension between the requirements of the curriculum, the students' learning needs and the needs of the clients. Consistent staffing of the clinic with students and appropriately 
Table 7 Evaluation Methods and Outcomes of SLCs

\begin{tabular}{|c|c|c|}
\hline Student-Led Clinic & Focus of Evaluation & Evaluation Method(s) \\
\hline $\begin{array}{l}\text { Auckland University of Technology } \\
\text { Integrated Health - } \\
\text { Interprofessional programmes* }\end{array}$ & $\begin{array}{l}\text { Explore and evaluate the experiences of } \\
\text { clients, students and educators. }{ }^{29,32} \\
\text { Explore student and educator experiences. }{ }^{30} \\
\text { Explore student perceptions of the placement } \\
\text { and the utility of the IPE Student } \\
\text { Questionnaire. } \\
\text { Explore service-user perspectives. }^{28}\end{array}$ & $\begin{array}{l}\text { - Phenomenological hermeneutic interpretive approach; } \\
\text { individual semi structured interviews with clients and } \\
\text { focus groups with students and educators. }{ }^{29,32} \\
\text { - Client demographic details, clinical indicators (BMI, waist } \\
\text { circumference, blood pressure, blood glucose) and } \\
\text { COPM scores. }^{32} \\
\text { - Focus groups. } \\
\text { - IPE Student Questionnaire. } \\
\text { - Qualitative descriptive design with an interpretative } \\
\text { approach using semi-structured interviews. }{ }^{28}\end{array}$ \\
\hline $\begin{array}{l}\text { Design for Health and Well-being } \\
(\mathrm{DHW}) \text { Lab }\end{array}$ & Not a formal evaluation. & - NA \\
\hline Otago Polytechnic massage clinic & No known formal evaluation. & - NA \\
\hline $\begin{array}{l}\text { Three unspecified clinics from } \\
\text { New Zealand and seventeen from } \\
\text { Australia }\end{array}$ & $\begin{array}{l}\text { Examine the goals, possibilities, and challenges } \\
\text { of university clinics. }\end{array}$ & $\begin{array}{l}\text { - Consultative enquiry conducted within a context-input- } \\
\text { process-products (CIPP) systems framework. } \\
\text { - Semi-structured interviews were conducted with people } \\
\text { in management, operations, or delivery of education } \\
\text { within a university clinic or who were students. }\end{array}$ \\
\hline $\begin{array}{l}\text { Unitec Osteopathy clinic (and } \\
\text { others from Australia and the } \\
\text { United Kingdom) }\end{array}$ & $\begin{array}{l}\text { Investigate the construct validity of the } \\
\text { Osteopathy Clinical Teaching Questionnaire as } \\
\text { used in student-led clinics. }\end{array}$ & - Rasch analysis. \\
\hline University of Otago & $\begin{array}{l}\text { Evaluate changes in student attitudes to } \\
\text { interprofessional practice, IPE, and the } \\
\text { effectiveness of health care teams. }\end{array}$ & - Focus groups with students and educators. \\
\hline $\begin{array}{l}\text { University of Otago physiotherapy } \\
\text { clinic }\end{array}$ & No known formal evaluation. & - NA \\
\hline $\begin{array}{l}\text { Victoria University psychology } \\
\text { centre }\end{array}$ & No known formal evaluation. & - NA \\
\hline Wintec Biokinetic clinic & For accreditation purposes. & - Accreditation checklist. \\
\hline
\end{tabular}

Note: *Also included in the consultation process.

qualified health professionals was frequently raised as a challenge to the successful delivery of clinics. Aligning these diverse needs and providing consistent service delivery proved challenging, particularly within the financial, fiscal, and timetabling constraints of educational institutions, which operate very differently to healthcare providers.

Many of the student-led health services had been evaluated from the students' perspective, fewer from the educators' perspective and only one from the service-user perspective. While student-led health services are often promoted as a vehicle for providing affordable, quality healthcare to communities with high needs, without formal evaluation this is purely an assumption.
Similar clinics internationally have evaluated the impact of healthcare delivered through a student-led health service on client outcomes, such as patient satisfaction, ${ }^{58,59}$ falls prevention, ${ }^{60}$ quality of mental health care, ${ }^{61}$ smoking cessation ${ }^{62}$ and screening rates. $^{36,63}$ The gap in empirical evaluation of student-led health services in Aotearoa New Zealand suggests that embedding data collection and analysis would be a useful approach when planning and developing any new student-led health service.

\section{Conclusion}

Undertaking what was a seemingly simple scoping review, about the development of student-led clinics, has alerted 
us to the wide range of models in practice, the complexity of operational medico-legal considerations, the importance of community consultation during the development and implementation of such an initiative and that risks and opportunities need to be thoughtfully considered and managed. Key learnings from this review point to the level of planning required to successfully establish and execute the operation of a student-led health service. Planning clearly needs to include: consultation; aligning curriculum design with opportunities in the placement experience; obtaining multiple perspectives and being deliberate about how the service best structured; having a clear vision and service objectives that are promoted by leadership; starting small and building up; recognising the substantial costs associated with healthcare provision that are not typically built into educational provider budgets; partnering with a community organization where possible; and embedding evaluation of the health service from the beginning.

\section{Acknowledgments}

We would like to thank those educators who provided their time as part of our consultation process. We also acknowledge colleagues at Wintec, who have contributed thoughts and suggestions to this review, namely, Greg Smith, Marrin Haggie, Kay Syminton, Ruth Martis, Ricky Bell, Oliver Wilson, Tame Pokaia and Hera White. Sharon Brownie now has an additional affiliation: School of Nursing, Midwifery \& Public Health, University of Canberra, Canberra, ACT, Australia.

\section{Disclosure}

This work was supported by Waikato Institute of Technology (Wintec) Seed funding. Ema Tokolahi, Amy Pearce, and Patrea Andersen report grants from Waikato Institute of Technology (Wintec), during the conduct of the study. The authors report no other potential conflicts of interest for this work.

\section{References}

1. Briggs L, Fronek P. Student experiences and perceptions of participation in student-led health clinics: a systematic review. J Soc Work Educ. 2020;56(2):238-259. doi:10.1080/10437797.2019.1656575

2. Schutte T, Tichelaar J, Dekker RS, van Agtmael MA, de Vries TPGM, Richir MC. Learning in student-run clinics: a systematic review. Med Educ. 2015;49(3):249-263. doi:10.1111/medu.12625

3. Ouyang D, Yuan N, Sheu L, Lau G, Chen C, Lai CJ. Community health education at student-run clinics leads to sustained improvement in patients' hepatitis b knowledge. J Community Health. 2013;38 (3):471-479. doi:10.1007/s10900-012-9631-3
4. Lee TC, Frangos SN, Torres M, Winckler B, Ji G, Dow E. Integrating undergraduate patient partners into diabetes self-management education: evaluating a free clinic pilot program for the underserved. $J$ Health Care Poor Underserved. 2016;27(4):1689-1708. doi:10.1353/hpu.2016.0156

5. Butala NM, Chang H, Horwitz LI, Bartlett M, Ellis P. Improving quality of preventive care at a student-run free clinic. PLoS One. 2013;8(11):1-6. doi:10.1371/journal.pone.0081441

6. Lee BJ, Wang SK, So C, et al. A student-led health education initiative addressing health disparities in Chinatown community. $\mathrm{Am}$ J Pharm Educ. 2015;79(9):132. doi:10.5688/ajpe799132

7. Stuhlmiller CM, Tolchard B. Developing a student-led health and wellbeing clinic in an underserved community: collaborative learning, health outcomes and cost savings. BMC Nurs. 2015;14(1):1-8. doi:10.1186/s12912-015-0083-9

8. Kenzie-Jones PR. Indigenous activism, community sustainability, and the constraints of CANZUS settler nationhood. Transmotion. 2019;5 (1):104-131.

9. Nikolakis W, Cornell S, Nelson HW. Reclaiming Indigenous Governance: Reflections and Insights from Australia, Canada, New Zealand, and the United States. University of Arizona Press; 2019.

10. Ford L. Locating Indigenous self-determination in the margins of settler sovereignty. In: Ford $\mathrm{L}$, Rowse $\mathrm{T}$, editors. Between Indigenous and Settler Governance. Routledge; 2012:1-11.

11. Czyzewski K. Colonialism as a broader social determinant of health. Int Indig Policy J. 2011;2(1). doi:10.18584/iipj.2011.2.1.5

12. Statistics New Zealand. New Zealand's population reflects growing diversity; 2019. Available from: https://www.stats.govt.nz/news/new-zealandspopulation-reflects-growing-diversity\#: :text.Accessed May 5, 2021.

13. OECD. Foreign-born population; 2021. Available from: https://data.oecd. org/migration/foreign-born-population.htm. Accessed May 5, 2021.

14. Vertovec S. Super-diversity and its implications. Ethn Racial Stud. 2007;30(6):1024-1054. doi:10.1080/01419870701599465

15. Daudt HML, Van Mossel C, Scott SJ. Enhancing the scoping study methodology: a large, inter-professional team's experience with Arksey and O'Malley's framework. BMC Med Res Methodol. 2013;13(1):1-9. doi:10.1186/1471-2288-13-48

16. Tricco AC, Lillie E, Zarin W, et al. A scoping review on the conduct and reporting of scoping reviews. BMC Med Res Methodol. 2016;16 (1):1-10. doi:10.1186/s12874-016-0116-4

17. O'Brien KK, Colquhoun H, Levac D, et al. Advancing scoping study methodology: a web-based survey and consultation of perceptions on terminology, definition and methodological steps. BMC Health Serv Res. 2016;16(1):1-12. doi:10.1186/s12913-016-1579-z

18. Aveyard H. Doing a Literature Review in Health and Social Care. Open University Press; 2018.

19. Aveyard H, Bradbury-Jones C. An analysis of current practices in undertaking literature reviews in nursing: findings from a focused mapping review and synthesis. BMC Med Res Methodol. 2019;19 (1):1-9. doi:10.1186/s12874-019-0751-7

20. Arksey H, O'Malley L. Scopins studies: towards a methodological framework. Int J Soc Res Methodol. 2005;8(1):19-32. doi:10.1080/ 1364557032000119616

21. Colquhoun HL, Levac D, O'Brien KK, et al. Scoping reviews: time for clarity in definition, methods, and reporting. J Clin Epidemiol. 2014;67(12):1291-1294. doi:10.1016/j.jclinepi.2014.03.013

22. Tricco AC, Lillie E, Zarin W, et al. PRISMA extension for scoping reviews (PRISMA-ScR): checklist and explanation. Ann Intern Med. 2018;169(7):467-473. doi:10.7326/M18-0850

23. Levac D, Colquhoun H, O'Brien KK. Scoping studies: advancing the methodology. Implement Sci. 2010;5(69):1-18. doi:10.1017/ cbo9780511814563.003

24. Ghalibaf AK, Nazari E, Gholian-Aval M, Tabesh H, Tara M. Comprehensive overview of computer-based health information tailoring: a scoping review protocol. BMJ Open. 2017;7(12):e019215. doi:10.1136/bmjopen-2017-019215 
25. Elsevier. Mendeley; 2020. Available from: https://www.mendeley.com/ homepage-2-1 ?interaction_required $=$ true\&adobe_mc_sdid $=\mathrm{SDID} \%$ 3D64C25792AA3B61ED-16D15DC322F56BBC\%7CMCORGID\% 3D4D6368F454EC41940A4C98A6\%40AdobeOrg\%7CTS\% 3D1599188878\&adobe_mc_ref=https\%3A\%2F\%2Fwww.mendeley. com\%2Fhomepage-2-1\%3Finteracti. Accessed July 21, 2021.

26. Peters MDJ, Godfrey CM, Khalil H, McInerney P, Parker D, Soares CB. Guidance for conducting systematic scoping reviews. Int $J$ Evid Based Healthc. 2015;13(3):141-146. doi:10.1097/ XEB.0000000000000050

27. Pham MT, Rajić A, Greig JD, Sargeant JM, Papadopoulos A, Mcewen SA. A scoping review of scoping reviews: advancing the approach and enhancing the consistency. Res Synth Methods. 2014;5 (4):371-385. doi:10.1002/jrsm.1123

28. Tucker L. Service users' views of collaborative care; 2012. Available from: http://hdl.handle.net/10292/5330. Accessed July 21, 2021.

29. Friary P, Tolich J, Morgan J, et al. Navigating interprofessional spaces: experiences of clients living with parkinson's disease, students and clinical educators. J Interprof Care. 2018;32(3):304-312. doi:10.1080/13561820.2017.1417238

30. Morgan CJ, Bowmar A, McNaughton S, Flood B, O’Brien D. Transformative learning opportunities for students and educators during interprofessional healthcare practice experiences in higher education: viewed through the lens of threshold concepts theory. Focus Health Prof Educ. 2019;20(2):41. doi:10.11157/fohpe. v20i2.301

31. O'Brien D, McCallin A, Basset S. Student perceptions of an interprofessional clinical experience at a university clinic. NZ J Physiother. 2013;41(3):81-87.

32. O'Brien D, McNaughton S, Flood B, Morgan J, Bowmar A. Piloting an integrated, interprofessional programme for people living with Type II diabetes: outcomes and experiences. Aust J Clin Educ. 2016;1(1):1

33. O'Brien D, Swann J, Heap N. Can the communities of practice model explain the complex organization of an interprofessional student-led health clinic? J Allied Health. 2015;44(1):E11-E16.

34. Godbold R, Lees A, Reay S. Ethical challenges for student design projects in health care settings in New Zealand. Int J Art Des Educ. 2019;38(1):182-192. doi:10.1111/jade.12170

35. Pullon S, McKinlay E, Beckingsale L, et al. Interprofessional education for physiotherapy, medical and dietetics students: a pilot programme. J Prim Health Care. 2013;5(1):52-58. doi:10.1071/ hc13052

36. Vaughan B. Exploring the measurement properties of the osteopathy clinical teaching questionnaire using Rasch analysis. Chiropr Man Therap. 2018;26(1):13. doi:10.1186/s12998-018-0182-2

37. Allan J, O'Meara P, Pope R, Higgs J, Kent J. The role of context in establishing university clinics. Health Soc Care Community. 2011;19 (2):217-224.

38. Flood B, McKinstry W, Friary P, Purdy SC. Cultivating interprofessional practice in New Zealand: an inter-sectorial approach to developing interprofessional education. J Allied Health. 2014;43(3):e59-e64.

39. Tikkanen R, Osborn R, Mossialos E, Djordjevic A, Wharton GA. International health care system profiles: New Zealand. The Commonwealth Fund; 2020. Available from: https://www.common wealthfund.org/international-health-policy-center/countries/newzealand. Accessed June 23, 2021.

40. Albinsson G, Elmqvist C, Hörberg U. Nursing students' and lecturers' experiences of learning at a university-based nursing student-run health clinic. Reflective Pract. 2019;20(4):423-436. doi:10.1080/14623943.2019.1638242

41. Weber EJ. Publication bias begins at home. Emerg Med J. 2019;36 (9):518-519. doi:10.1136/emermed-2019-208857

42. Borges NJ, Hartung PJ. Service learning in medical education: project description and evaluation. Int $J$ Teach Learn High Educ. 2007;19(1):1.
43. Seif G, Coker-Bolt P, Kraft S, Gonsalves W, Simpson K, Johnson E The development of clinical reasoning and interprofessional behaviors: service-learning at a student-run free clinic. $J$ Interprof Care. 2014;28(6):559-564. doi:10.3109/13561820.2014.921899

44. Ko J, Connor S, Jonkman L, Abraham O. Student pharmacists' perspectives on service-learning experiences in free clinics. $\mathrm{Am}$ J Pharm Educ. 2019;83(9):7379. doi:10.5688/ajpe7379

45. Hand J, Koransky A, Feinman J, et al. Alumni perspectives on the role of medical school service learning experiences in their professional development and practice. J Health Care Poor Underserved. 2018;29(4):1386-1399. doi:10.1353/hpu.2018.0102

46. Bell CL Impact of nursing students' free-clinic experiences on subsequent professional nursing practice; 2013.

47. Scott EA, Swartz MK. Interprofessional student experiences on the HAVEN free clinic leadership board. J Interprof Care. 2015;29 (1):68-70. doi:10.3109/13561820.2014.934339

48. Campos-Outcalt DE. Specialties chosen by medical students who participated in a student-run, community-based free clinic. Am J Prev Med. 1985;1(4):50-51. doi:10.1016/S0749-3797(18)31400-4

49. Modi A, Fascelli M, Daitch Z, Hojat M. Evaluating the relationship between participation in student-run free clinics and changes in empathy in medical students. J Prim Care Community Health. 2017;8(3):122-126. doi:10.1177/2150131916685199

50. Nakamura M, Altshuler D, Binienda J. Clinical skills development in student-run free clinic volunteers: a multi-trait, multi-measure study. BMC Med Educ. 2014;14(1):250. doi:10.1186/s12909-014-0250-9

51. Heller M, Thomas AM, Peters SM, Düsterwald KM, Klausner JD. An evaluation of patient and student experience at a longstanding student-run free clinic in Cape Town, South Africa. Cureus. 2019;11(12):e6320.

52. Chopra N, Zhou DB, Fallar R, Chadha N. Impact of near-peer education in a student-run free ophthalmology clinic on medical student teaching skills. J Surg Educ. 2020;77(6):1503-1510. doi:10.1016/j.jsurg.2020.05.012

53. Ministry of Health. Ministry of Health reports on Māori health outcomes and disparity in outcomes between Māori and non-Māori from 1992 to 2016. 2017;(June):1-13. Available from: https://www.health. govt.nz/system/files/documents/pages/ministry_of_health_reports on_maori_health_outcomes.pdf. Accessed July 21, 2021.

54. Sciascia A. Māori Learner Success in Tertiary Education: Highlights from Ako Aotearoa Supported Research Projects. Ako Aotearoa; 2017.

55. Graham R, Masters-Awatere B. Experiences of Māori of Aotearoa New Zealand's public health system: a systematic review of two decades of published qualitative research. Aust $N Z J$ Public Health. 2020;44(3):193-200. doi:10.1111/1753-6405.12971

56. Lewis R, Kelly S. Changing hearts and minds: examining student nurses' experiences and perceptions of a general practice placement through a "community of practice" lens. BMC Med Educ. 2018;18 (1):1-10. doi:10.1186/s12909-018-1182-6

57. Dancza K, Warren A, Copley J, et al. Learning experiences on roleemerging placements: an exploration from the students' perspective. Aust Occup Ther J. 2013;60(6):427-435. doi:10.1111/1440-1630.12079

58. Forbes R. Service dissatisfaction and non-attendance in physiotherapy student-led clinics: a qualitative study. Physiother Theory Pract. 2019;1-9. doi:10.1080/09593985.2019.1570576

59. Forbes R, Nolan D. Factors associated with patient-satisfaction in student-led physiotherapy clinics: a qualitative study. Physiother Theory Pract. 2018;34(9):705-713. doi:10.1080/ 09593985.2018.1423592

60. Bonner A, MacCulloch P, Gardner T, Chase C. A student-led demonstration project on fall prevention in a long-term care facility. Geriatr Nurs (Minneap). 2007;28(5):312-318. doi:10.1016/j.gerinurse.2007.04.014

61. Liberman KM, Meah YS, Chow A, Tornheim J, Rolon O, Thomas DC. Quality of mental health care at a student-run clinic: care for the uninsured exceeds that of publicly and privately insured populations. J Community Health. 2011;36(5):733-740. doi:10.1007/ s10900-011-9367-5 
62. Lough LE, Ebbert JO, McLeod TG. Evaluation of a student-run smoking cessation clinic for a medically underserved population. BMC Res Notes. 2011;4(1):55. doi:10.1186/1756-0500-4-55

63. Hu ZI, Smith DM. Cancer screening rates in a student-run free clinic. Ochsner J. 2016;16(1):37-40.
64. Liberati A, Altman D, Tetzlaff J, et al. The PRISMA statement for reporting systematic reviews and meta-analyses of studies that evaluate health care interventions: explanation and elaboration. Journal of Clinical Epidemiology. 2009;62(10):e1-e34.

\section{Publish your work in this journal}

The Journal of Multidisciplinary Healthcare is an international, peerreviewed open-access journal that aims to represent and publish research in healthcare areas delivered by practitioners of different disciplines. This includes studies and reviews conducted by multidisciplinary teams as well as research which evaluates the results or conduct of such teams or healthcare processes in general. The journal covers a very wide range of areas and welcomes submissions from practitioners at all levels, from all over the world. The manuscript management system is completely online and includes a very quick and fair peer-review system. Visit http://www.dovepress.com/testimonials. php to read real quotes from published authors. 